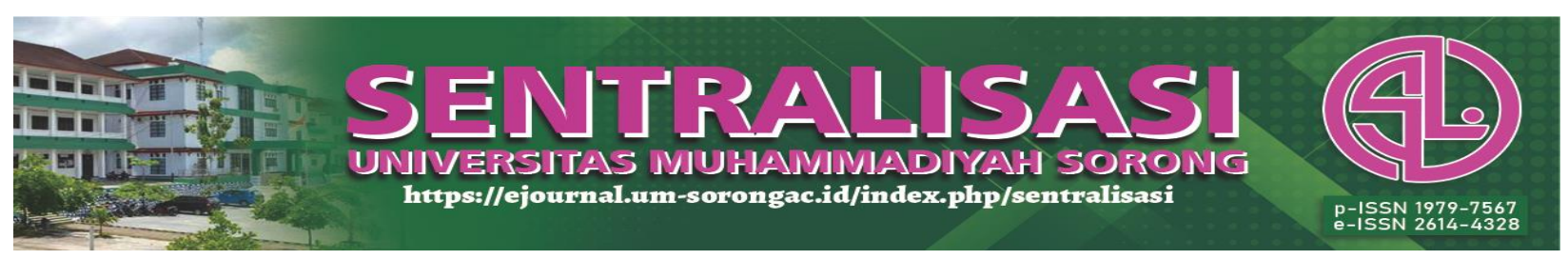

\title{
Determinant Analysis of Corporate Social Responsibility Disclosure in Food and Beverages Company
}

\author{
Dwi Cahyono ${ }^{1}$, Intan Sarifa Nuraeni ${ }^{2}$ \\ 1,2, Faculty of Economics and Business, Muhammadiyah University of Jember, Indonesia
}

Email: dwicahyono@unmuhjember.ac.id

revised: 20/01/2021 dipublikasikan: 31/01/2021

\begin{abstract}
Abstrak. Kelestarian lingkungan sekitar memiliki peran yang besar dan penting dalam kesuksesan sebuah perusahaan. Tolak ukur keberhasilan organisasi dapat dilihat dari kinerja keuangan perusahaan yang dialokasikan untuk pengungkapan Corporate Social Responsibility (CSR). Pengungkapan Corporate Social Responsibility (CSR) sebagai kepedulian perusahaan terhadap lingkungan sekitar, dan akhirnya akan mempengaruhi keberlangsungan perusahaan. Perusahaan yang baik rutin melakukan pengungkapan Corporate Social Responsibility (CSR). Banyak penelitian telah dilakukan dengan meneliti determinan dalam pengungkapan Corporate Social Responsibility (CSR). Namun, beberapa hal tidak menunjukkan keberhasilan dan terdapat kesenjangan penelitian. Hasil penelitian berpengaruh besar terhadap pengungkapan Corporate Social Responsibility (CSR). Pengambilan keputusan ini didasarkan pada teori yang ada.
\end{abstract}

Kata kunci : Kinerja Lingkungan, Komite Audit, Profitabilitas, Leverage, Ukuran Perusahaan, CSR Disclosure.

\begin{abstract}
The environmental sustainability has a big and important role in the success of a company. Organizational benchmarks can be seen from the company's financial performance which is allocated for Corporate Social Responsibility (CSR) disclosure. Corporate Social Responsibility (CSR) Disclosure is the company's concern for its surrounding environment, which will affect the sustainability of the company. Good companies regularly disclose their Corporate Social Responsibility (CSR). Many studies have been conducted by examining the determinants in Corporate Social Responsibility (CS) disclosure. However, several things do not show that the research have a big effect on Corporate Social Responsibility (CSR) disclosure. This decision making is based on existing theory
\end{abstract}

Keywords : Environmental Performance, Audit Committee, Profitability, Leverage, Company Size, CSR Disclosure

\section{Introduction}

Corporate Social Responsibility (CSR) concept has been used in many business corporate, professional committe dan academics, along with it gaps. Corporate Social Responsibility commonly divided into three (3) elements : environment, economic and social, although there is no proper agreement how to implement the idea to the practice (Haynes et al., 2012). Therefore, business challenge cannot be defined as CSR, but to comprehend how CSR be built in certain social context and how to consider about it when bussiness strategy is being developed. (Dahlsrud, 2008).

To formulate a strategy of CSR that can be successfully applied, company should be aware that the advantages of CSR will depend on mediating variables and situational continuity (Carroll 


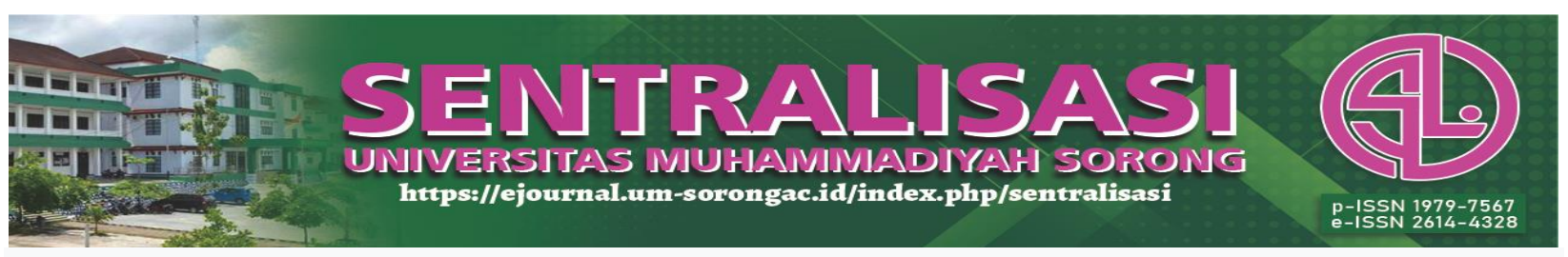

\& Shabana, 2010). In Indonesia, the responsibility of social (Corporate Social Responsibility Disclosure) regulated in (Republik Indonesia, 2007) dealing with Limited Liability Company. Company has to responsible to its environment as its obligation which calculated and budgeted as cost, in which the application should be conducted by considering the rulling and reasonable aspect (Merina \& Noviardy, 2015).

Company could be fined or punished accordance with the rule if it doesn't carry out the obligastion. However, in practice there are common for a difference of opinion and interest between management and shareholders (McWilliams et al., 2006). It effects the interest conflict which is known as agency problem. Therefore to in process of overseeing and coordinating the interest between management and shareholders could raised agent costs (Kurnianingsih, 2013). One of the strategy to reduce agency cost is by increasing the management ownership and institutional ownership (Eriandani et al., 2019). When considering of having high ownership, the shareholders expected to focus on increasing company's value and applying CSR.

The case that happened in Food And Beverages company for instance in PT. Ultrajaya Milk Industry Tbk in 2017 which having the lowest value of CSR Disclosure in the company namely 0,16 or $16 \%$, which means the implementation of social disclosure of enviromental awareness in PT. Ultrajaya Milk Industry Tbk is low. Meanwhile, the highest CSR Disclosure value is in PT. Wilmar Cahaya Indonesia Tbk in 2016 namely 0,69 or 69\% because there are many social diclosure program in the company, one of the example is by giving various aidand goods to the local residents of the company. Moreover PT. Wilmar Cahaya Indonesia Tbk assists the increasing of local residents' standard of living, and builds some infrastructures around the company. The differences of CSR disclosure between PT. Ultrajaya Milk Industry Tbk and PT. Wilmar Cahaya Indonesia Tbk caused uneven disclosure therefore it is badly needed the firm regulation from the government. Thus research is amied to retest what factors that affect the CSR Disclosure in Food And Beverages companies.

\section{Research Method}

\section{Analysis Data Technique}

Statistic description used to serve and analize data along with the calculation to clarify the situation or characteristic of related data.

\section{Multiple Linear Regression Analysis}

Analysis Data technique which is uesd in this research is multiple linear regression analyis. $\mathrm{Y}=\mathrm{a}+\mathrm{b}_{1} \mathrm{X}_{1}+\mathrm{b}_{2} \mathrm{X}_{2}+\mathrm{b}_{3} \mathrm{X}_{3}+\mathrm{b}_{4} \mathrm{X}_{4}+\mathrm{b}_{5} \mathrm{X}_{5}+\mathrm{e}$

Information:

a

$b_{1} b_{2} b_{3} b_{4} b_{5}$

$\mathrm{X}_{1}$

\section{: Constant}

: Regression coefficient

: Environment Performance Variable/KL 


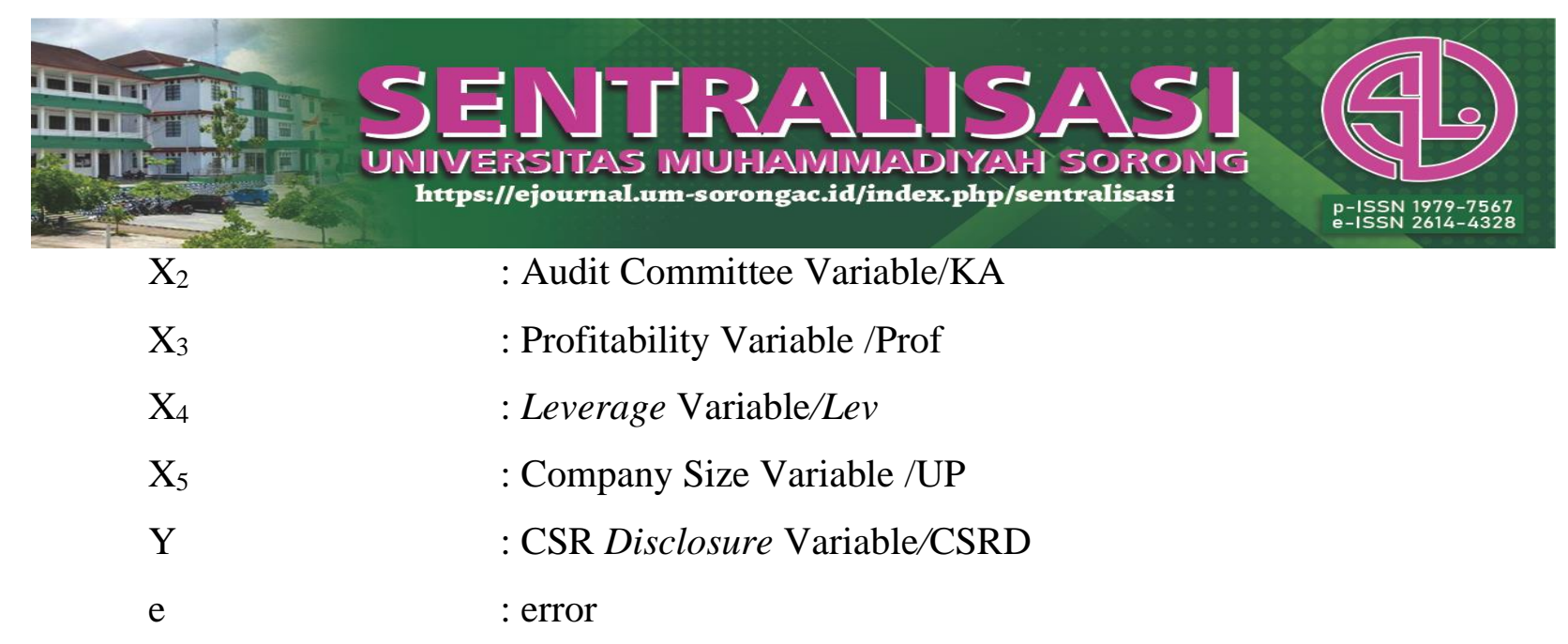

\section{Result dan Discussion}

\section{Statistical Description}

Tabel 1. Statistical Description Result

\begin{tabular}{lccccc}
\hline \multicolumn{1}{c}{ Research Variables } & $\mathrm{N}$ & Min & Max & Mean & Deviation Standart \\
\hline Environment Performance/KL $\left(\mathrm{X}_{1}\right)$ & 13 & 3 & 5 & 3,64 & 0,7265 \\
Audit Committee/KA $\left(\mathrm{X}_{2}\right)$ & 13 & 3 & 4 & 3,07 & 0,2606 \\
Profitability/Prof $\left(\mathrm{X}_{3}\right)$ & 13 & $-0,11$ & 0,71 & 0,13 & 0,1567 \\
Leverage/LEV $\left(\mathrm{X}_{4}\right)$ & 13 & $-1,53$ & 1,87 & 0,85 & 0,6286 \\
Company Size/UP $\left(\mathrm{X}_{5}\right)$ & 13 & 6,34 & 30,33 & 20,27 & 7,1633 \\
CSR Disclosure/CSRD (Y) & 13 & 0,16 & 0,69 & 0,31 & 0,1139 \\
\hline
\end{tabular}

Resource: Processed data, 2020

The samples which used in this research is 30 gained from the annual report and from those 30 there are only 13 food and beverages company around 2016-2018 period that could be analyzed. PT Tri Banyan Tirta Tbk in 2016 has lowest Enviromental Performance value, this is caused by the low PROPER value as the result of the low application of social awareness. Meanwhile the highest Enviromental Performance is PT. Indofood Sukses Makmur Tbk in2018. Based on PROPER published by Ministry of Environment and Forestry establish that PT. Indofood Sukses Makmur Tbk has fullfill the disclosure for instance energy efficiency, emosol decline, water efficiency, etc.

On other hand, PT. Delta Djakarta Tbk in 2016 has the lowest Audit Committee value, committee proportion consists of audit committee chairman, secretary and members of audit committee. The highest value of Audit Committee is PT Tiga Pilar Sejahtera Food Tbk in 2016 with the complete structure of audit committee, it is expected that committe audit members should have proper understanding about the principle of internal control and the process of making financial statement. The lowest value of Audit Committee is PT Tiga Pilar Sejahtera Food Tbk in 2017 it is caused by net profit income of the company is not high enough, which cause low ROA value meanwhile the highest profitability in 2017 is PT. Multi Bintang Indonesia Tbk which able to gain high net profit income therefore the ROA value is high.

In 2018 the lowest Leverage value is PT Tiga Pilar Sejahtera Food Tbk this result caused by the company's capital adequacy in funding operational activities so that it can reduce company's leverage level. The higest value of Leverage is PT. Prashida Aneka Niaga Tbk in 2018 


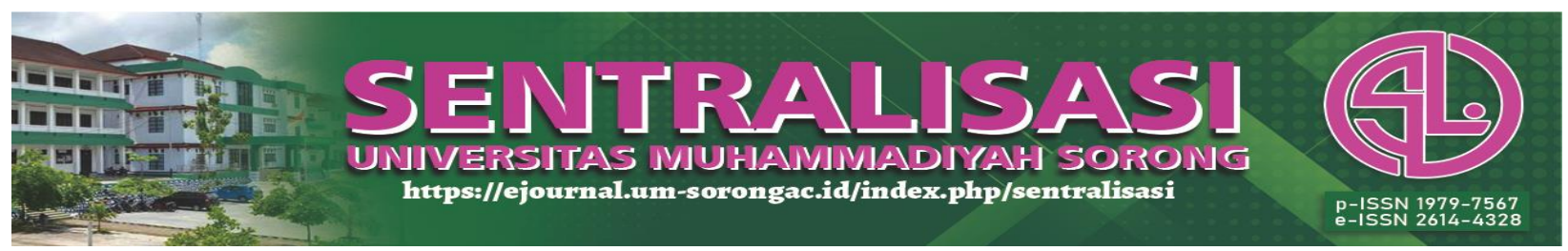

it is caused by the high use of leverage in company's capital which affects the company's ability in generating high net profit income. PT. Sekar Laut Tbk in 2018 has the lowest Company Size, it is caused by the low assets of the company. Meanwhile the highest Company Size is PT. Mayora Indah Tbk in 2017, it is caused by the high assets of the company affect the high firm size. PT. Mayora Indah Tbk ability to gain the assets comes from the increasing company's profit every year.

In 2017 PT. Ultrajaya Milk Industry Tbk has lowest CSR Disclosure value, it can be said that the company's implementation of the item of social disclosure to the enviromental awarnesss is low. Meanwhile the highest value of CSR Disclosure is PT. Wilmar Cahaya Indonesia Tbk in 2016. This high value is as the result of many social programs disclosure for instance provise various kinds of aids and goods for the local residents to increase their living as well as bulid the infrastructure of the local residents.

\section{Multiple Regression Linear Analysis}

The result of multiple linear analysis to research hypothesis shown in Table 2 as follows:

Tabel 2. Multiple Regression Linear Analysis Result

\begin{tabular}{lccl}
\hline \multicolumn{1}{c}{ Variabel } & $\begin{array}{c}\text { Regression } \\
\text { Coefficient }\end{array}$ & Sig. & \multicolumn{1}{c}{ Information } \\
\hline Environmental Performance/KL (X1) & 0,107 & - & - \\
Audit Committee/KA (X2) & 0,774 & 0,013 & Significant \\
Profitability/Prof (X3) & 0,362 & 0,168 & Not Significant \\
Leverage/LEV (X4) & 0,406 & 0,022 & Significant \\
Company Size/UP (X5) & 0,229 & 0,027 & Significant \\
CSR Disclosure (Y) & 0,473 & 0,042 & Significant \\
\hline
\end{tabular}

Resource: Processed data, 2020

Regression equation result is as follow:

$Y=0,107+0,774 X_{1}+0,362 X_{2}+0,406 X_{3}+0,229 X_{4}+0,473 X_{5}+e$.

\section{Discussion}

\section{The effect of Environmental Performance on CSR Disclosure}

Environmental Performance effects on CSR Disclosure. As a part of strategy to mantain the relation with stakeholder is by doing social responsibility (Corporate Social Responsibility). Corporate Social Responsibility is expected by the stakeholder can be accomodated, as the result it will make a good relation between company and its stakeholder in achieving company's sustainability.

Supporting by agencies especially government agencies dealing with company;s environmental awarness will affect to the corporate's environmental performance. Environmental performance will gain high level is the company consistently performs various controlled environmental management actions. Good environmental performers believe that by revealing the environmental performace it will give a good news to stakeholder. 


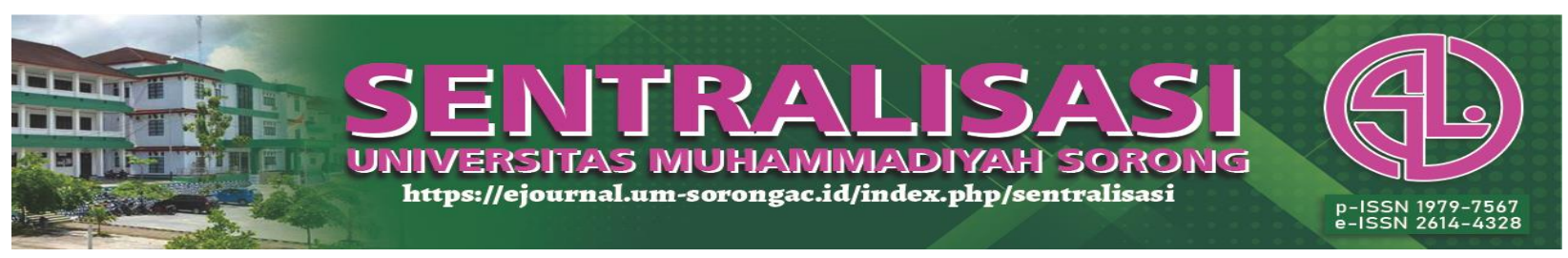

\section{The effect of Audit Committee on CSR Disclosure}

Audit Committe does not effect on CSR Disclosure it is because the large number of audit committees can not be a parameter of efectivity supervision to company's management. Otherwise, descriptive analysis result of this research shown that mostly company's samples has audit committe's member consist of 3 people. This is accordance with decision of Bapepam chaiman no.Kep-29/PM/2004 as well as the regulation no.IX.I.5 that audit committee which is own by the company should be at least consist 3 people, where at least 1 person is Independent Commissioner and 2 other members are from public agency or emiten. Therefore it can be concluded that Audt Committee has no effet on CSR Disclosure it is because possibily the amount of these audit comittee is just formality as a basis to fullfill the decision of Bapepam cahirman,so that audit committee does not consider company's effectivity.

\section{Profitability effect on CSR Disclosure}

Profotabilty effect on CSR Disclosure. Profitability can be proxied as change in auditor. Change in auditor is the changing external auditor in conducting audit. In conducting audit process it can be determined whether the company implemeting CSR or not. If the company doesnot change the auditor there is a possibility that the auditor understand the risk and business process, or even can detect CSR actions of the company. Otherwise, to reduce the possibility of detecting CSR actions, commonly the compny will change its auditor to cover it. Company is demand to improve its performance so that the return on investment of principal (such as dividen) will be increase, as the result principal will gives appreciation to the agen (Profitabilitas).

\section{Leverage effect onCSR Disclosure}

Leverage will effect onCSR Disclosure. Company with high Leverage ratio will reveal more information, because comapny's agent costs with capital structure will be higher. So that it can be said that if company has high Leverage ration it will has an obligation to reveal wider information than the low one. Leverage or solvability mainly used as a paramater to measure company's assets which are financed by short term debt or long term debts. This is related to the usage of own capital and loan capital, from those it can be known whether the capitals are accordance to company's policy and goals or not, they also provide assurance about how much debt of the company can be covered by the company's capital.

Leverage can also measure how well the investment structure in the company is. The higher Leverage level, the higher the usage of debts in financing the investment to assets, which caused the increasing of company's risks. This is related to Sembiring, 2002 which states that the bigger company with its operational activities will have bigger influence to the society and the shareholders who aware of the social program made by the company will make the corporate social responsibility disclosure will get wider effect. 


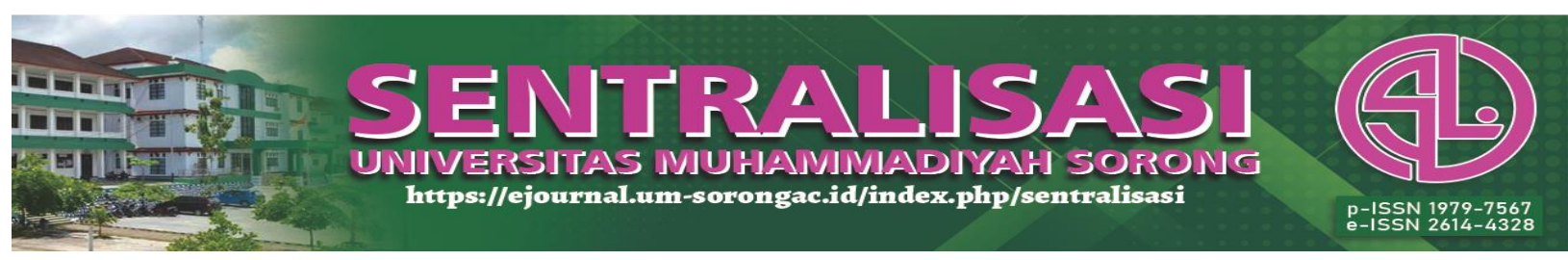

\section{Company Size effect on CSR Disclosure}

Company size effect on CSR Disclosure. Big company will do more activities that have

big impact to society, so that the company will consider its social program. Big company has bigger political costs than small company. This is related to Anggraini (2006) opinion which is stated that big company has bigger political cost than the small one. Big company tend to reveal lower profit than the small one, so that big company will spend greater cost for disclosing social information bigger than small company. This is related to the legitimation theory that company size related to CSR disclosure (Milne \& Hackston, 1996). Similar opinion aslo stated by (Cowen et al., 1987) that big company will do more activities that give big impactto society, so that the company will consider of its social awarness.

\section{Conclusion}

Regarding to the discussion and result it can be concluded that firts, Environmental Performance effects on CSR Disclosure. Environmental Performance effects on it because environmental is a part of strategy to maintain the relation with company's stakeholders by doing Corporate Social Responsibility. Second, Audit Committee does not effect on CSR Disclosure, it is because the large amount of audit committee does not refelct company's success in controlling the effectivity to company's management. Third, Profitability effects on CSR Disclosure. The company that try to decrease the possibility of detecting CSR actions commonly change its auditor more often. Suggestion, for the next research it will be better if the sampel of the research get the wider sample criteria for instance manufacture or other for example metal and mineral mining company listed in Indonesia Sock Exchange (BEI).

\section{References}

Anggraini, Retno. (2006). Pengungkapan Informasi Sosial dan Faktor-Faktor yang Mempengaruhi Pengungkapan Informasi Sosial dalam Laporan Keuangan Tahunan (Studi Empiris pada Perusahaan-Perusahaan yang terdaftar di Bursa Efek Jakarta). Proceding Simposium Nasional Akuntansi IX. Padang.

Ardhani Ika Sulistyawati, R. L. P. dan D. T. (2016). Pengungkapan Corporate Social Responsibility Pada Laporan Keuangan Dan Determinasinya. Seminar Nasional IENACO 2016.

Carroll, A. B., \& Shabana, K. M. (2010). The business case for corporate social responsibility: A review of concepts, research and practice. International Journal of Management Reviews, 12(1), 85-105. https://doi.org/10.1111/j.1468-2370.2009.00275.x

Cowen, S. S., Ferreri, L. B., \& Parker, L. D. (1987). The impact of corporate characteristics on social responsibility disclosure: A typology and frequency-based analysis. Accounting, Organizations and Society, 12(2), 111-122. https://doi.org/10.1016/0361-3682(87)90001-8

Dahlsrud, A. (2008). How corporate social responsibility is defined: An analysis of 37 definitions. Corporate Social Responsibility and Environmental Management, 15(1), 1-13. https://doi.org/10.1002/csr.132 


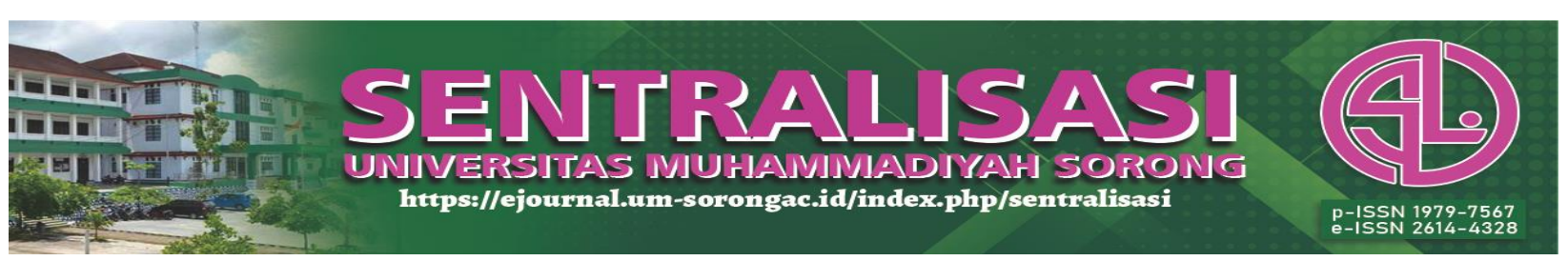

Eriandani, R., Narsa, I. M., \& Irwanto, A. (2019). Pengaruh pengungkapan risiko lingkungan terhadap likuiditas dan biaya modal saham. Jurnal Ekonomi Dan Bisnis. https://doi.org/10.24914/jeb.v22i2.2356.

Ghozali, I. (2016). Ghozali, Imam. (2016). Aplikasi Analisis Multivariate dengan Program IBM SPSS 23. Semarang: BPFE Universitas Diponegoro. IOSR Journal of Economics and Finance.

Haynes, K., Murray, A., \& Dillard, J. (2012). Corporate social responsibility. In Corporate Social Responsibility: A Research Handbook. https://doi.org/10.4324/9780203106082

Kurnianingsih, H. T. (2013). Pengaruh Profitabilitas Dan Size Perusahaan Terhadap Corporate Social Responsibility. Jurnal Riset Akuntansi Dan Bisnis.

McWilliams, A., Siegel, D. S., \& Wright, P. M. (2006). Corporate social responsibility: Strategic implications. In Journal of Management Studies. https://doi.org/10.1111/j.14676486.2006.00580.x

Merina, C. I., \& Noviardy, A. (2015). Analisis Determinan Pengungkapan Corporate Social Responsibility (CSR) Perusahaan Go Public Di Indonesia. Bina Darma E-Journal.

Milne, M. J., \& Hackston, D. (1996). Some determinants of social and environmental disclosures in New Zealand companies. Accounting, Auditing \& Accountability Journal, 9(1), 77-108.

Republik Indonesia, . (2007). Undang - Undang No. 40 Tahun 2007 tentang Perseroan Terbatas. Lembaran Negara RI Tahun 2007.

Sembiring, ER (2005), „Karakteristik perusahaan dan pengungkapan tanggung jawab social: studi empiris pada perusahaan yang tercatat di Bursa Efek Jakartaee, Simpsium Nasional Akuntansi VII solo, 15-16 September 2005, hlm.379-395.

Sugiyono. (2012). Metode Penelitian Kuantitatif, Kualitatif dan R \& D.Bandung:Alfabeta. Metode Penelitian Kuantitatif, Kualitatif Dan $R \quad \& \quad$ D.Bandung:Alfabeta. https://doi.org/10.1017/CBO9781107415324.004 